\title{
A revision of the Mediterranean Raphitomidae, 8: on two poorly known species of Raphitoma Bellardi, 1847: R. pumila (Monterosato, 1890) and R. hispidella nomen novum (Gas- tropoda Conoidea)
}

\author{
Riccardo Giannuzzi-Savelli", Francesco Pusateri² \& Stefano Bartolini ${ }^{3}$ \\ ${ }^{1}$ Via Mater Dolorosa 54, 90146 Palermo, Italy; e-mail: malakos@tin.it \\ ${ }^{2}$ Via Castellana 64, 90135 Palermo, Italy; e-mail: francesco@pusateri.it \\ ${ }^{3}$ Via E. Zacconi 16, 50137 Firenze, Italy; e-mail: stefmaria.bartolini@libero.it \\ *Corresponding author
}

ABSTRACT

Two poorly known species of genus Raphitoma Bellardi, 1847 (Gastropoda Conoidea) are revised. Raphitoma pumila (Monterosato, 1890) is redescribed and Cordieria cordieri var. hispida, Monterosato, 1890 is raised to species level and transferred to the genus Raphitoma, hence requiring the creation of a replacement name ( $R$. hispidella nomen novum) due to secondary homonymy with $R$. hispida Bellardi, 1877.

KEY WORDS Raphitomidae; revision; taxonomy; nomen novum.

Received 10.01.2019; accepted 13.03.2019; published online 30.03.2019

\section{INTRODUCTION}

The Raphitomidae are currently considered as a well-supported clade of the Conoidea (Bouchet et al., 2011), worthy of family ranking. It is probably the most diverse family of Conoidea, in terms of species richness, ecological range and anatomical disparity (Kantor \& Taylor, 2002), and are therefore considered as potentially ideal candidates for toxin discovery (Puillandre et al., 2017).

We are currently revising the Raphitomidae of the Mediterranean Sea and adjacent Atlantic coasts. We provisionally estimated ca. 50 Mediterranean extant species, some of which still undescribed. The taxon Raphitomidae Bellardi, 1875 is based on the genus Raphitoma Bellardi, 1847 which was introduced as comprising 34 fossil and recent species (Bellardi 1847: 85), previously classified in various genera (such as Pleurotoma and Clathurella).
During this revision, we have found a quite rare species of Raphitoma described by Monterosato (1890) as a variety of the so called Cordiera reticulata $(=$ Raphitoma echinata). In our opinion it is a good species having its own peculiar characteristics

\section{MATERIAL AND METHODS}

Our approach was exclusively based on shell morphology due to the almost total lack of anatomical data.

Specimens studied come from private collections (see Abbreviations).

Light photographs were taken (if not otherwise stated) by Stefano Bartolini using a Canon EOS 400D digital photocamera, with standard objective $50 \mathrm{~mm}+$ adapted lens (25 and $12.5 \mathrm{~mm}$ ) for 16 
and $8 \mathrm{~mm}$ vintage cine camera and by Yves Lafontaine.

ABBREVIATIONS AND ACRONYMS. BAR: Stefano Bartolini Firenze, Italy; BOG: Cesare Bogi (Livorno, Italy); CHI: Francesco Chiriaco (Livorno, Italy); CRO: Paolo Crovato (Napoli, Italy); LAF: Yves Lafontaine (Fréjus, France); MCZR: Museo Civico Zoologia, Roma, Italy; MRSNT: Museo Regionale Storia Naturale, Terrasini (Palermo, Italy); OZT: Bilal Oztürk (Izmir, Turkey); PAG: Attilio Pagli (Lari, Italy); PAO: Paolo Paolini (Livorno, Italy); PIS: Michele Pisanu (Cagliari, Italy); PKR: Jakov Prkić (Split, Croatia); PUS: Francesco Pusateri (Palermo, Italy); QUA: Ermanno Quaggiotto (Vicenza, Italy); RON: Francesco Roncone (Cosenza, Italy); SMR: Carlo Smriglio (Roma, Italy); SPA: Maria Teresa Spanu (Alghero, Italy). H/W: height/width ratio; SD: Standard Deviation; sh/s: shell/s.

\section{Raphitoma pumila (Monterosato, 1890)} (Figs. 1-7)

Pleurotoma (Homotoma) reticulata var. pumila Monterosato, 1878: 106 (nomen nudum)

Cordieria reticulata var. pumila Monterosato, 1890: 187

Cordieria pumila Appolloni et al., 2018: 66

ORIGINAL DIAGNosis. Monterosato (1890): "Cordieria reticulata var. pumila Monts. - Più corta; si direbbe una forma nana, spesso incolore, reticolazione più fitta, bocca fortemente dentata - Funnazzi, Algeria, Lipari etc." (shorter; it would seem a dwarf form, often colorless, denser cross-linking, strongly toothed mouth - Funnazzi, Algeria, Lipari etc.)

TYPE MATERIAL. MCZR-M 16774: Lectotype from Algeria ( $14 \times 6.3 \mathrm{~mm}$, labelled "tipo") and paralectotypes from Palermo (16.7 x $7.8 \mathrm{~mm}$ and $14.3 \times 7.5 \mathrm{~mm}$ ). According the ICZN art. 72.4 .7 the term "tipo" of the labels is not necessarily an evidence that this specimen is the "holotype". However we respect the indication of Monterosato and fix this specimen as a lectotype.

TYPE LOCALITY. Algeria.

EXAMINED MATERIAL. The type material and: France. Saint-Raphaël, port du Poussaï, Le Dramont, 1 sh (LAF).
Italy. Sardinia: La Maddalena, 1 sh (SPA). Sicily: No locality, 1 sh (MCZR-M 16903); Mare di Sicilia, 1 sh (MRSNT n. 29823), sub nomine $R$. reticulata; Ficarazzi, 2 shs (PUS); Brucoli, 1 sh (PUS).

Morocco. Alboran Sea, 1 sh (PUS).

Algeria. No locality, 1 sh (SPA).

DESCRIPTION. In square brackets the data of the holotype. Shell biconic squat, of medium size for the genus, height: $9-17 \mathrm{~mm}$, mean: 13.9, SD: 2.41 [14]; width: 5-8.6 mm, mean: 6.9, SD: 1.12 [6.3]; H/W: 1.91-2.22, mean: 2.02, SD: 0.11 [2.22].

Protoconch multispiral, rust brown in colour, of 2.75 convex whorls, height $483 \mu \mathrm{m}$, width $460 \mu \mathrm{m}$, protoconch I of 1.1 whorls, covered by thin cancellations, protoconch II with a diagonally cancellated sculpture starting after a zone under the suture with fine axial threads. The last whorl shows a keel before the onset of the teleoconch. Protoconch-teleoconch boundary slightly flexuose, opisthocline. Teleoconch of 5.5-7.5 [6.5] rounded whorls, stout, suture incised, sculpture robust. Densely disseminated microgranules in the surface. Axial sculpture of 14-18 [16] orthocline (occasionally slightly opisthocline or prosocline), equidistant ribs, and interspaces larger than the ribs in the last whorl, narrower in the others. Spiral sculpture above the aperture of 5 to 6 [6] cordlets. Sometime 1 or 2 supplementary small cordlets can occur. Cancellation rectangular, with strong, elongated and acute tubercles at the intersections. Subsutural ramp large, with one or two small spiral cordlets. Columella simple, slightly sinuous anteriorly. Outer lip thick with 9-12 strong inner denticles [12], the 2 most anterior more robust and delimiting the short but wide and conical siphonal canal. Siphonal fasciole with 6-9 [7] nodulose cords with first 3 more strong. Colour uniformly light straw sometime with a pale brownish band around the suture and on the low part of the last whorl. Occasionally comma-shaped white spots on the subsutural ramp. Sometime there are whitish chevron among axial ribs of the last whorl.

Soft parts unknown.

Distribution. This quite rare species seems to occur only in the Western and Central Mediterranean.

Comparative notes. This species is quite similar to one of the morphotypes of $R$. echinata (Brocchi, 1814) (Figs. 8-10) but differs having a lower 


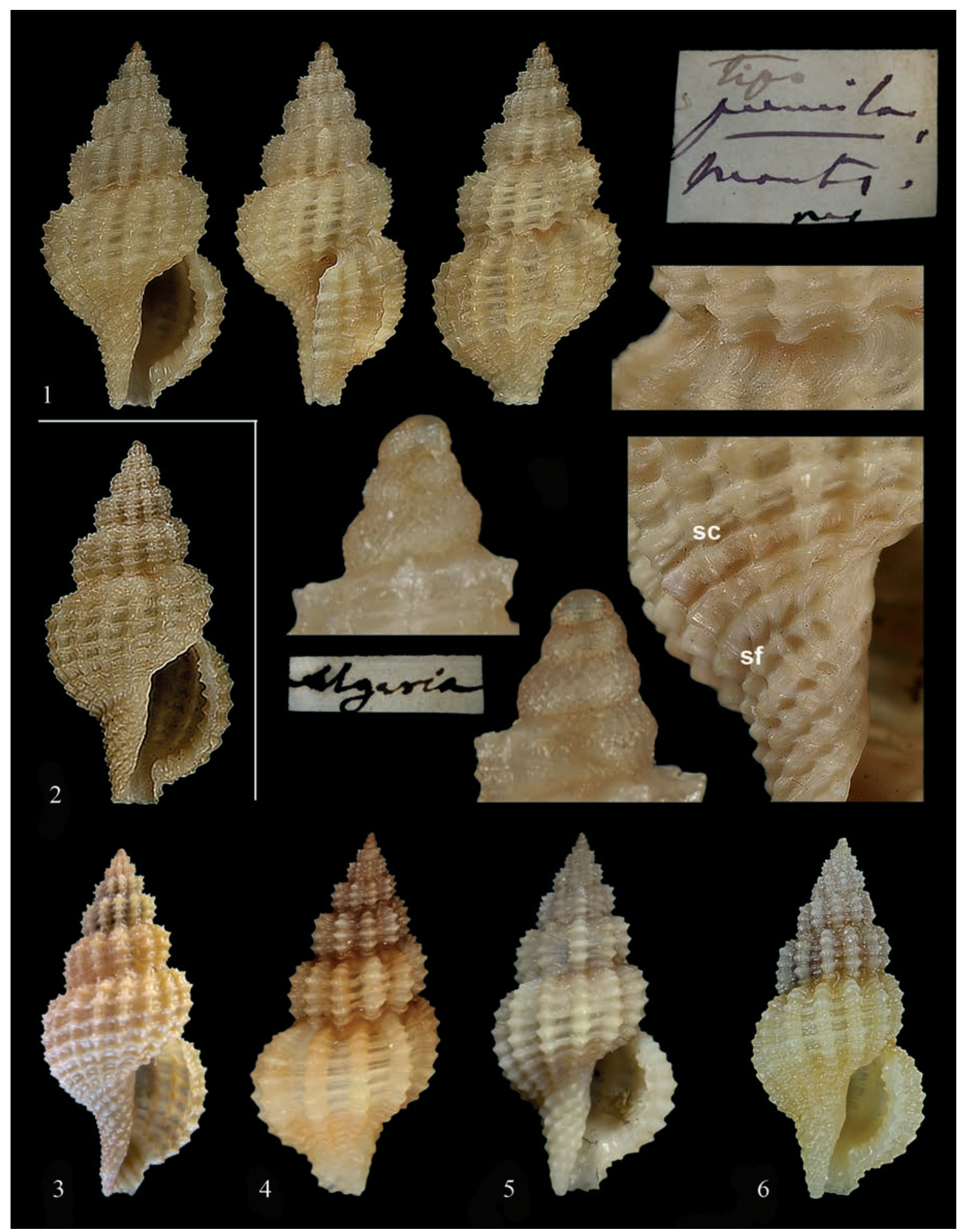

Figures 1-6. Shells of Raphitoma pumila (Monterosato, 1890). Fig. 1: Lectotype, Algeria (MCZR-M-16774), h: 14 mm with 2 original labels, particular of subsutural zone, particular of the secondary cordlet (sc) and of the starting point of siphonal fasciole (sf), and protoconch (2 view). Fig. 2: type B, Palermo (Italy), (MCZR-M-16774), h: 14.3. Fig. 3: Algeria, h: 14 mm. Fig. 4: St. Raphael (France), h: 9.6 mm. Fig. 5: St. Raphael (France), h: 9.8 mm. Fig. 6: Castiglioncello, Livorno (Italy), h: 12 mm. Figs. 4, 5: photos courtesy by Gilles Devauchelle. 


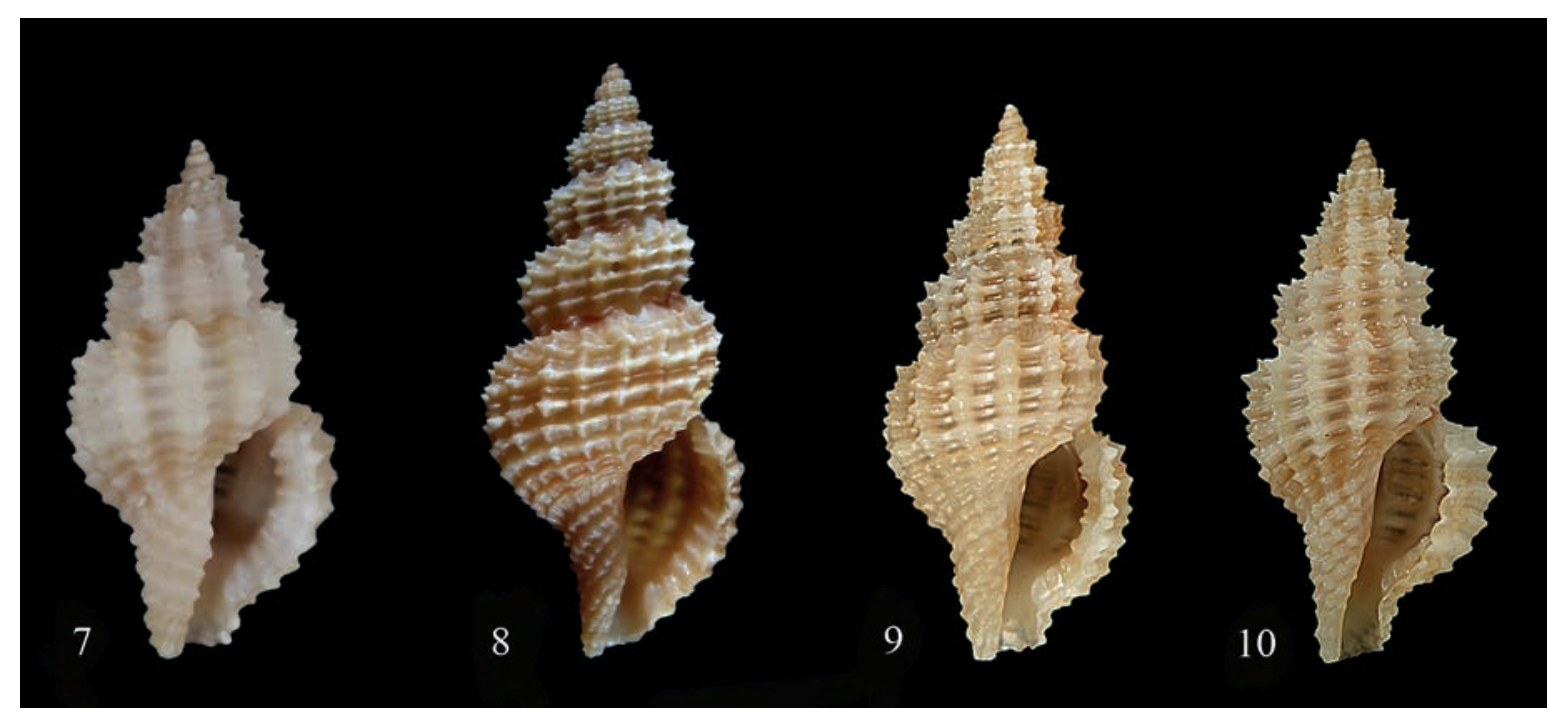

Figures 7-10. Raphitoma pumila (Monterosato, 1890). Fig. 7: S. Raphael (France), h: $11 \mathrm{~mm}$. Figs. 8-10: shells of a morphotype of Raphitoma echinata AA. Fig. 8: Channel of Hvar (Croatia), h: $21.1 \mathrm{~mm}$. Fig. 9: Costa del Sol (Spagna), h: 15 mm. Fig. 10: Montecristo Island (Italy), h: $8.3 \mathrm{~mm}$.

$\mathrm{H} / \mathrm{D}$, apical angle wider, more stout axial ribs, last whorl lower, outer lip thicker, the shorter siphon and having a less inclined suture.

REMARKS. This species introduced by Monterosato (1878: nomen nudum) was validated by Monterosato itself (1890) who gave a short but clear description.

Raphitoma hispidella Pusateri et GiannuzziSavelli nomen novum

Cordieria cordieri var. hispida, Monterosato, 1890: 187, non Raphitoma hispida Bellardi, 1877

Cordieria hispida, Appolloni et al., 2018: 65, figs. $22 \mathrm{O}-\mathrm{P}$

Raphitoma echinata sensu Manousis et al. 2018: 27 fig. 21c

Original Diagnosis. Monterosato (1890): "CC. cordieri, Payr. (Pleurot.) - Una piccola forma che può distinguersi come: Var. hispida, Monts. - A scultura hispida e pungente; molto più piccola del tipo, un terzo. Gli esemplari freschi sono trasparenti e color di ambra. L'apice a (sic!) molti giri torricolati e punteggiati. Nella C. reticulata è revoluto".

TyPe Material. Lectotype here designated, MCZR-M-17442 (10 x $4.4 \mathrm{~mm})$ and 4 paralecto- types ( 2 probably referred to $R$. brunneofasciata and 2 juveniles) with handwritten labels by Monterosato: C. hispida./ Monts/ms.", "H. hispida, Monts./mss./Palermo, profonda/Si trova anche nell'/Atlantico ad Ar-/cachon (De Boury). (Da non confondere/con hispidula Brocc.)".

TYPE MATERIAL. MCZR-M-17442 - 3 shs labelled: H. hispida Monts. Palermo"; 2 shs labelled: hispida Monts. Palermo comunicat." // "Atlantico ad Arcachon (De Boury). (Da non confondere con hispidula Brocc." // C. hispida Monts Med".

Type LOCALity. Palermo.

EXAMINED MATERIAL. The type material and: Atlantic. France. Capbreton (Nouvelle Aquitaine), MCZR- M-17442 with handwritten label by Monterosato: "Cap Breton/De Folin" 1 sh. Portugal. Algarve, 5 shs (PUS).

Mediterranean. Alboran, 1 sh (PUS). Spain. Barcelona, 1 sh (PAG).

Corse. Bastia, 2 sh (PAG); idem, 3 shs $-50 \mathrm{~m}$ (MCZR-M-17442) sub nomine Pl. cordieri.

Italy. Isola d'Elba, 1 sh (PUS); Capo Enfola, Isola d'Elba (Portoferraio, Toscana), $-6 \mathrm{~m}, 5 \mathrm{shs}$ (PAO); Secca delle Vedove -130, about 20 miles SW Gorgona Island (Tuscany Arch.), 2 shs (PAO); Antignano (Livorno), 1 sh (PAG); Castiglioncello (Livorno), 1 sh (BOG); Calambrone (Pisa) -30 m, 1 sh (BAR); Golfo di Baratti (Piombino, Livorno), 


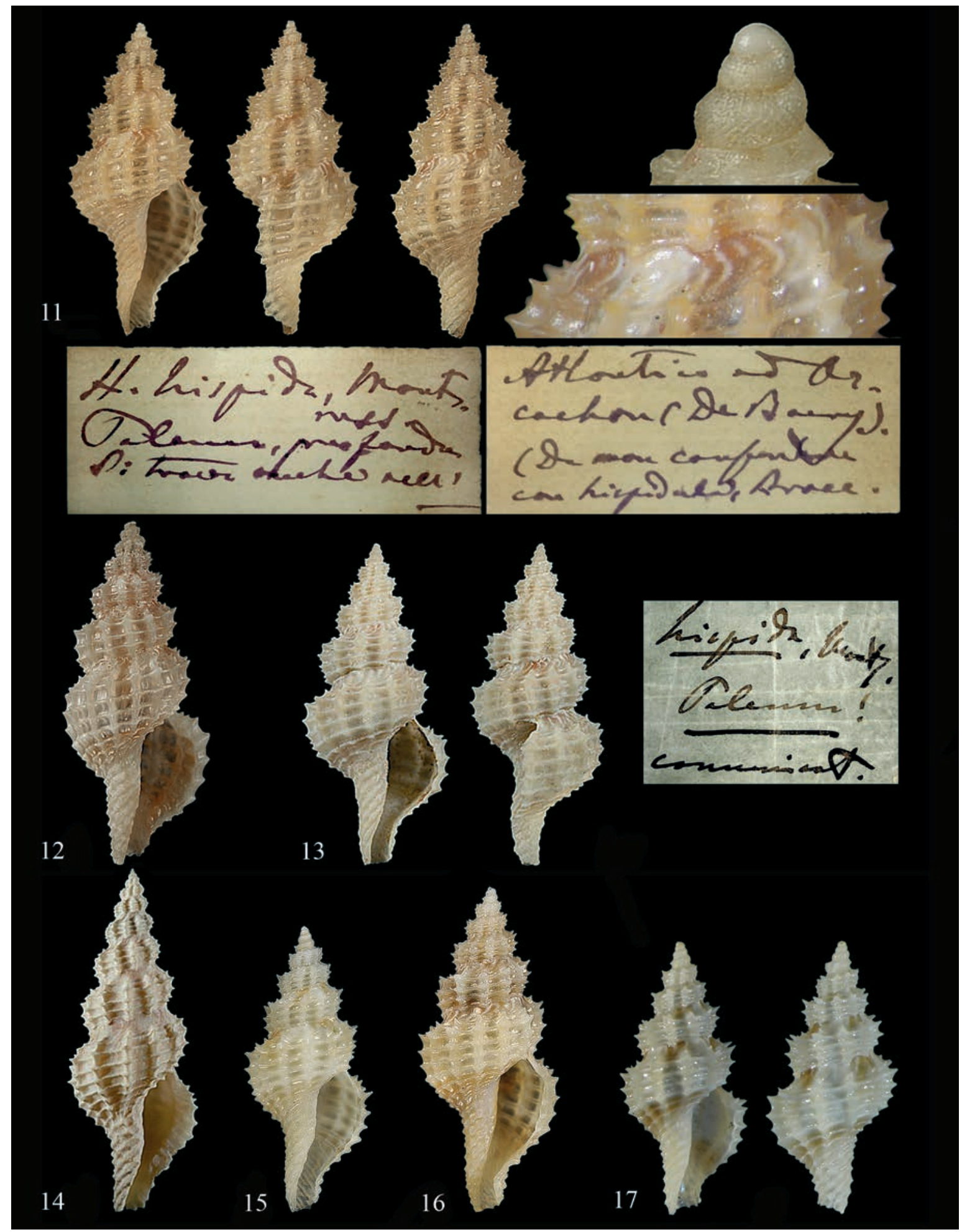

Figures 11-17. Raphitoma hispidella Pusateri et Giannuzzi-Savelli nomen novum. Fig. 11: Lectotype, Palermo (Italy), MCZR-M-17442, h: $10 \mathrm{~mm}$, with original label (recto/verso), protoconch and particular of subsutural zone. Fig. 12: Napoli (Italy), MCZR-M-17442, h: 12.8 mm. Fig. 13: Palermo (Italy), MCZR-M-16476), h: 8 mm, with original label. Fig. 14: Rab Island (Croatia), -80 m, h: 11.8. Fig. 15: Rab Island (Croatia), h: 6.5 mm. Fig. 16: Rab Island (Croatia), h: 9 mm. Fig. 17: Güllük Bay (Turkey), -44 m, h: 5.5 (photo courtesy by Bilal Oztürk). 


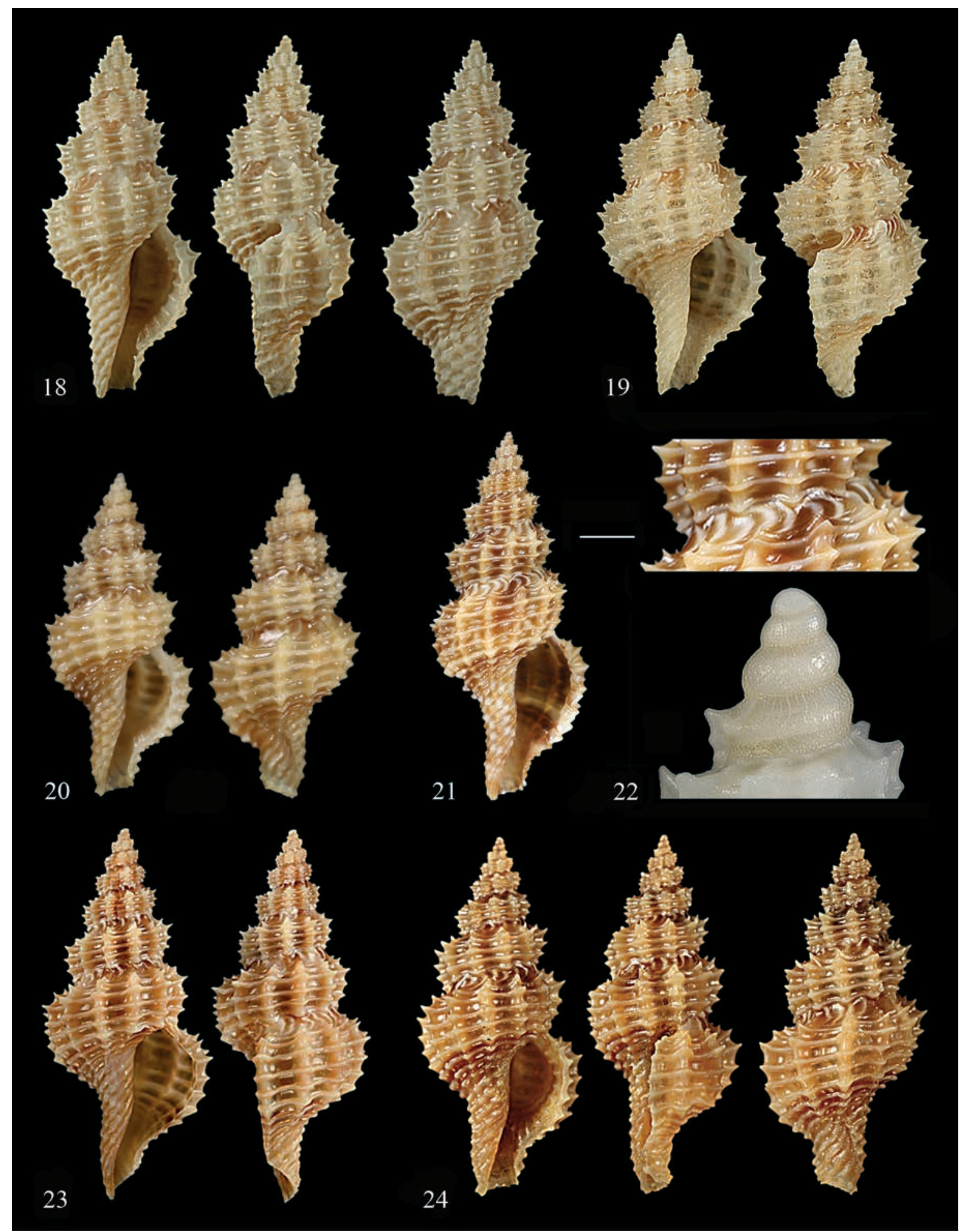

Figures 18-24. Raphitoma hispidella Pusateri et Giannuzzi-Savelli nomen novum. Fig. 18: Sant'Antioco Island (Carbonia-Iglesias, Italy), h: 9.5 mm. Fig. 19: Elba Island (Tusca Archipelago, Italy), h: 9.5 mm. Fig. 20: Isola delle Femmine (Palermo, Italy), h: $9.1 \mathrm{~mm}$. Fig. 21: Aci Trezza (Catania, Italy), - $80 \mathrm{~m}$, h: $15 \mathrm{~mm}$, with particular of subsutural zone. Fig. 22: protoconch from the specimen of figure 15. Fig. 23: Circeo (Latina, Italy), -90, h: $11.3 \mathrm{~mm}$. Fig. 24: Cagliari (Italy), h: $9.1 \mathrm{~mm}$. 


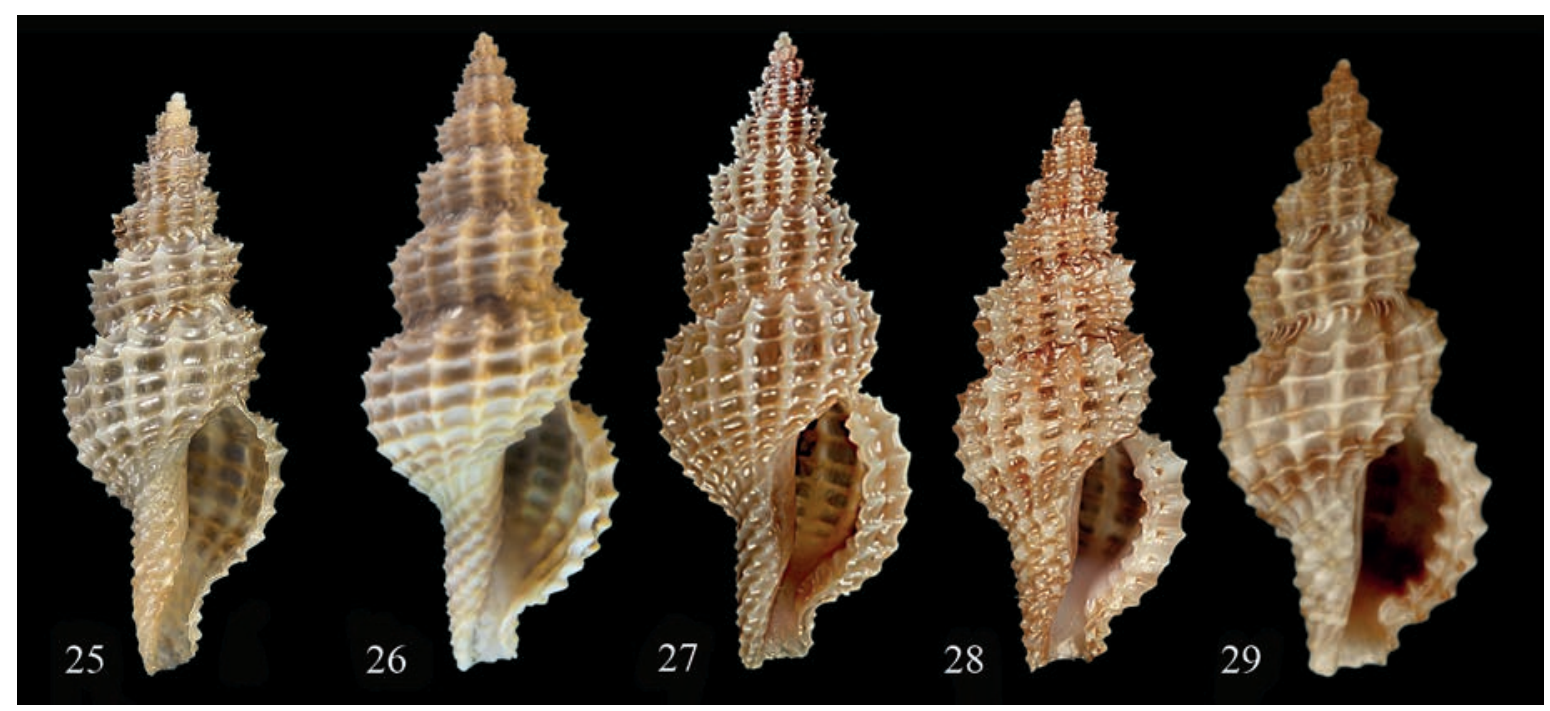

Figures 25-29. Fig. 25: Raphitoma hispidella Pusateri et Giannuzzi-Savelli nomen novum. Calambrone (Pisa, Italy), -30 m, h: 11.5 mm; Fig. 26: Raphitoma cordieri AA., Alghero (Sassari, Italy), h: mm 23.7; Fig. 27: Raphitoma cordieri AA., Napoli (Italy), h: 21 mm; Fig. 28: Raphitoma echinata AA., Saronikos (Greece), h: 9.2 mm; Fig. 29: Raphitoma horrida (Monterosato, 1884), Palermo (Italy), h: mm 12.

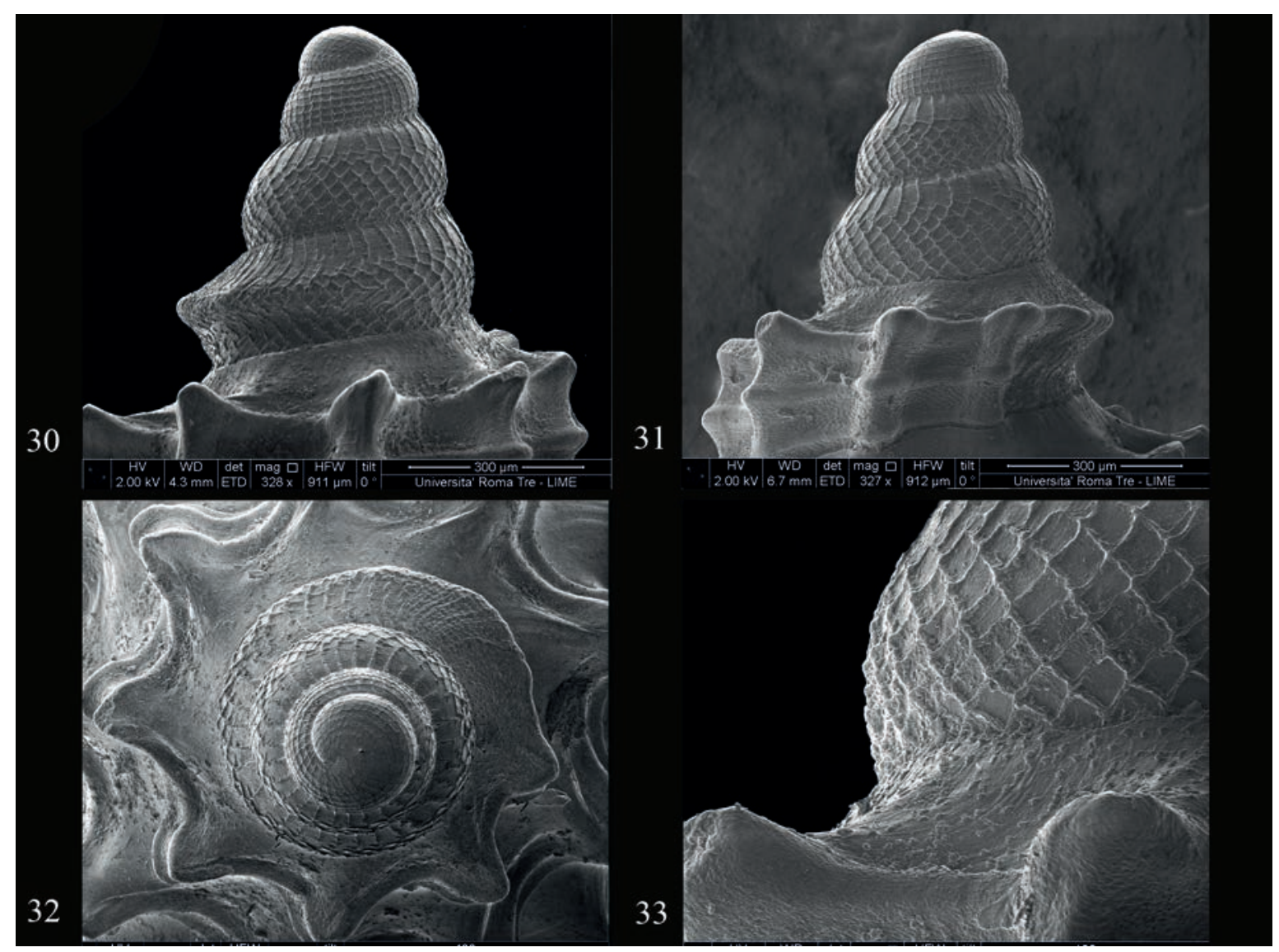

Figures 30-33. Raphitoma hispidella nomen novum, protoconch. Fig. 30: frontal view.

Fig. 31: dorsal view. Fig. 32: apical view. Fig. 33: protoconch/teleoconch boundary with microgranules. 


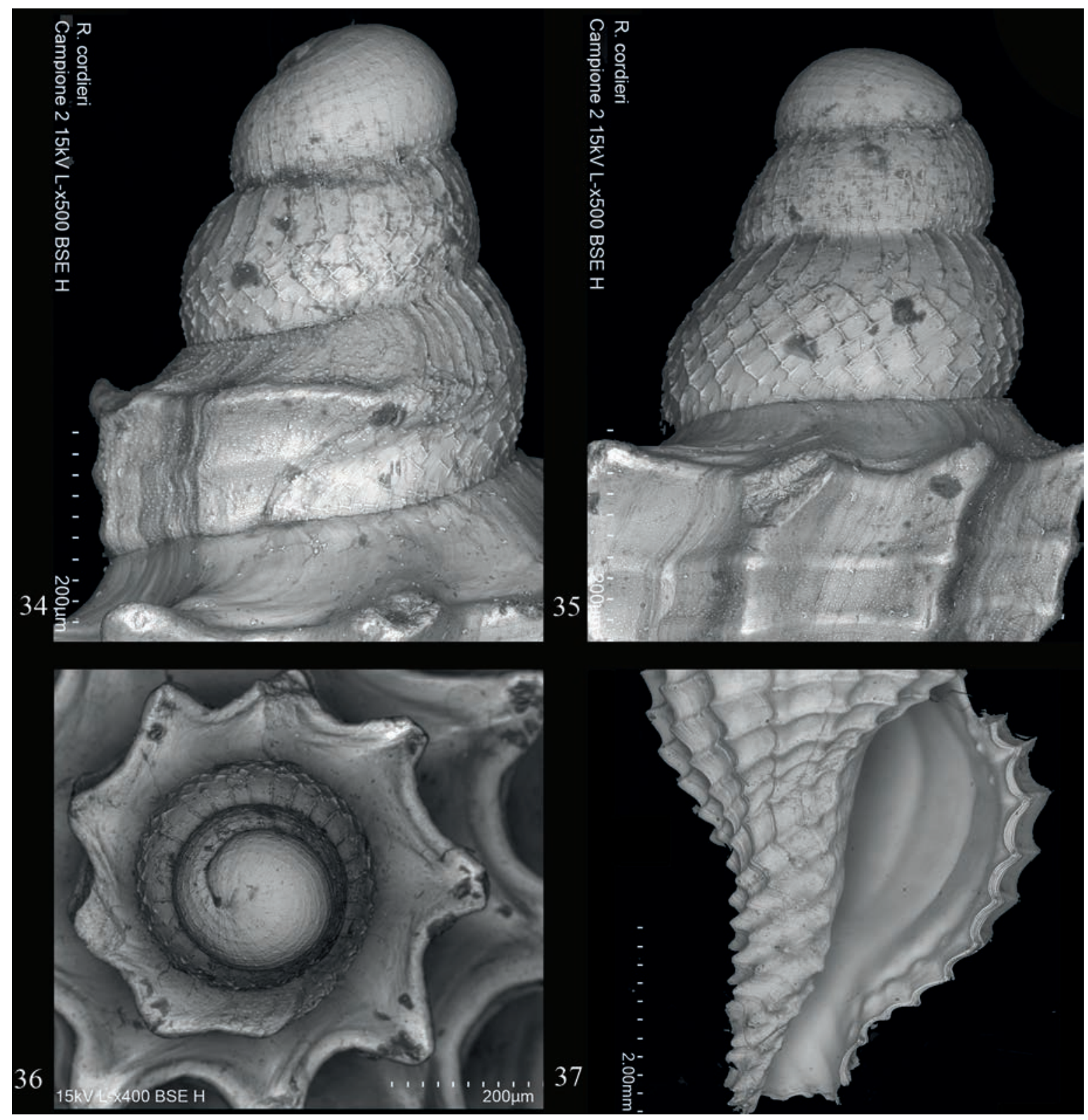

Figures 34-37. Raphitoma cordieri AA. Fig. 34: protoconch in frontal view.

Fig. 35: protoconch in dorsal view. Fig. 36: protoconch in apical view. Fig. 37: siphonal fasciole.

$-5 \mathrm{~m}, 4$ shs (PAO); Fiumicino (Roma) - $160 \mathrm{~m} ., 1 \mathrm{sh}$ (SMR); S. Felice Circeo (Latina), 1 sh (SMR); Napoli, 1 sh (MCZR-M-17442 sine nomine with Monterosato's label "non è cordieri!"; Cetraro (Cosenza), 1 sh (RON); Civitanova Marche (Macerata), 1 sh (CRO); Ortona (Chieti), 2 shs (QUA); S. Benedetto del Tronto (Ascoli Piceno), $-80 \mathrm{~m}, 2$ shs (PAO), 2 shs -80 m (BOG). Sardinia: Cagliari, 1 sh (PIS). Sicily: Ficarazzi, 3 shs (PUS); Palermo, 1 sh (MCZR-M-16476) sub nomine $C$. cordieri;
Isola delle Femmine (Palermo), 3 shs (PUS), 1 sh (CRO); Acicastello (Catania), -100, 2 shs (PUS); Acitrezza (Catania), -80, 1 sh (CHI); Brucoli (Siracusa), 1 sh (PUS).

Tunisia. Djerba, 1 sh (PUS).

Croatia. Supetar (Brac Island), 1 sh (PAG); Veli Rat (Dugi Otok Island), 1 sh (PUS); Rab Island, 4 shs (BAR); Dubrovnik, 1 sh (PKR).

Turkey. Güllük Bay (Aegean Sea), 2 shs (OZT). 
DESCRIPTION. In square brackets the data of the lectotype. Shell fusiform, of medium size for the genus, height 7-16.5 [10] mm, mean: 10.8, DS: 2.98 [10]; width 3.3-6.6 mm, mean: 4.76, DS: 1.17 [4.4]; H/W 2.12-2.47, mean 2.25, DS: 0.11 [2.27]. Teleoconch of 5.5-7 [6] convex whorls, fusiform and thin, suture thin, sculpture raised. Scattered microgranules in the surface of part of the first teloconch whorl. Axial sculpture of 11-14, mean: 12, DS: 0.98 [13] orthocline, equidistant ribs, and interspaces three times wider than the ribs. Spiral sculpture of 5-6 mean [5] cordlets thinner than the axial ribs, above the aperture. Cancellation rectangular, with strong and sligthly acute spines at the intersection of axials and spirals. Subsutural ramp wide, inclined and slightly arched. Columella simple, "s" slightly sinuous or almost straight anteriorly, angled posteriorly. Siphonal channel long and open that sometime can be twisted. Outer lip thin with 9-12 mean 10 [peristome not complete] weak inner lyrate denticles. Siphonal fasciole with 8-9 cords [8]. Colour variable from uniformly yellow straw in the background (from ligth to dark), up to bright brown. On the last whorl is present a darker subsutural band. Comma-shaped white spots on the darker subsutural ramp. Enterely white specimens are known. The darker specimens are typical in the coralligenous biocenosis.

Soft parts unknown.

Distribution. Mediterranean Sea and atlantic coasts of Portugal, Spain and France in the circalittoral zone.

REMARKS. Cordieria cordieri var. hispida Monterosato, 1890 is a valid taxon, which we deem deserving the rank of a species (and is an available name under art. 45.6.4 of the ICZN), although belonging to the genus Raphitoma, hence Raphitoma hispida (Monterosato, 1890) n. comb. The new combination makes the name hispida Monterosato, 1890 a secondary homonym (ICZN art. 59) of $R$. hispida Bellardi, 1877 (see Bellardi, 1877) so a new name is necessary and we propose hispidella nomen novum, diminutive adjective of the Latin word "hispida".

In the original description Monterosato (1890) compares this "variety" with Cordieria reticulata (= Raphitoma echinata) stating that this has a "revolute apex" (paucispiral). A rather surprising statement because Monterosato (1884: 131) describes it instead with "apice conico, acutissimo, composto di tre giri di spira punteggiati" (conical apex, very acute, composed of three punctuated whorls).

We believe this so-called variety is a good species. It differs constantly, without intermediates, by $R$. cordieri (Payraudeau, 1826) for: always smaller dimensions ( $\max 16.3$ vs. 25); very large and arched subsutural ramp vs. large and inclined; different size of protoconch (600 x $509 \mu \mathrm{m}$ vs. 475 x $350 \mu \mathrm{m}$ ) and different number of whorls (3 vs 2.3); for their yellow straw/witish protoconch vs. milk white; more bristly and scaled profile versus less brittle and regular; shorter and open siphonal channel; lack of supplementary cordlets sometimes present in $R$. cordieri; rectangular cancellations vs. subquadrate; siphonal fasciole with less strong and closer nodules; siphonal fasciole with 8-9 nodulose cordlets vs. 6-7; thin, lirates and well-spaced teeth vs, lirates, evidents with some cordlets rather strong.

Raphitoma hispidella could be confused with some morphs of $R$. echinata but the last have a shorter siphonal channel, stronger inner denticles and is more robust. Raphitoma horrida (Monterosato, 1884) resemble in some way to R. hispidella but can be easily separated having only 4 cordlets above the aperture, the shorter siphonal channel and more rounded and low aperture.

\section{ACKNOWLEDGMENTS}

The following colleagues are heartily thanked for their help with museum samples under their care: B. Cignini and M. Appolloni (MCZR, Roma, Italy); Piera Iacopelli (MRSNT, Terrasini, Palermo, Italy). We also wish to thank the friends for help with samples from their collections, Carlo Smriglio (Roma, Italy) for their usual help, Andrea Di Giulio (Roma, Italy) for the $R$. hispidella SEM photographs, Nanovision, Brugherio for $R$. cordieri SEM photographs and André Hoarau (Fréjus, France), Gilles Devauchelle (Fréjus, France) and Bilal Oztürk Izmir (Turkey) that provided us with some data and photos. This work was financially supported by Naturama Association, Palermo (Italy).

\section{REFERENCES}

Appolloni M., Smriglio C., Amati B., Lugliè L., Nofroni I., Tringali L., Mariottini P. \& Oliverio M., 
2018. Catalogue of the primary types of marine molluscan taxa described by Tommaso Allery Di Maria, Marquis of Monterosato, deposited in the Museo Civico di Zoologia, Roma. Zootaxa, 4477: 1-163. https://doi.org/10.11646/zootaxa.4477.1.1.

Bellardi L., 1847. Monografia delle Pleurotome fossili del Piemonte. Memorie della Reale Accademia delle Scienze di Torino, serie 2, 9: 531-650, 4 pls. [R. Janssen, 1993, said that the journal issue was published in 1848 but that a separate was distributed in 1847; the title and pagination for the separate is: Monografia delle Pleurotome Fossili del Piemonte. Torino, 119 pp.].

Bellardi L., 1877. I molluschi dei terreni terziarii del Piemonte e della Liguria. Parte II. Memorie della Reale Accademia delle Scienze di Torino, serie 2, 29: 1-373, 9 pls.

Bouchet P., Kantor Y.I., Sysoev A. \& Puillandre N., 2011. A new operational classification of the Conoidea. Journal of Molluscan Studies, 77: 273-308.

ICZN. International Commission on Zoological Nomenclature, 1999. International code of zoological nomenclature. 4th Edition. International Trust for Zoological Nomenclature, London, xxix +306 pp. on line version at: http://www.iczn.org/iczn/index. jsp
Kantor Y.I. \& Taylor J.D., 2002. Foregut anatomy and relationships of raphitomine gastropods (Gastropoda: Conoidea: Raphitominae). In: Oliverio M. \& Chemello R. (Eds.), Systematics, Phylogeny and Biology of the Neogastropoda. Bollettino Malacologico, 38, Supplement 4: 83-110.

Manousis T., Kontadakis C., Mbazios G. \& Polyzoulis G., 2018. The family Raphitomidae (Mollusca: Gastropoda: conoidea) in the Greek Seas with the description of two new species. Journal of Biological Reasearch - Thessaloniki, 25: 14. https://doi.org/10. 1186/s40709-018-0085-3

Monterosato M. Di, 1878. Enumerazione e sinonimia delle conchiglie mediterranee. Giornale Scienze Naturali ed Economiche di Palermo, 13: 61-115.

Monterosato M. Di, 1884. Nomenclatura generica e specifica di alcune conchiglie mediterranee. Stabilimento Tipografico Virzì, Palermo, pp. 152.

Monterosato M. Di., 1890. Conchiglie della profondità del mare di Palermo. Il Naturalista siciliano, 9: 181191.

Puillandre N., Fedosov A.E. \& Kantor Y.I., 2017. Systematics and Evolution of the Conoidea. In: Gopalakrishnakone P. \& Malhotra A., Evolution of Venomous Animals and Their Toxins. Springer, pp. 367-398. 